\title{
PELATIHAN DIGITALISASI PENGEMBANGAN KEWIRAUSAHAAN DAN PEMBUATAN LAPORAN KEUANGAN SEDERHANA BAGI PERSEKUTUAN WANITA GEREJA KRISTEN PROTESTAN DI BALI
}

\author{
Ni Luh Putu Sri Purnama Pradnyani ${ }^{1}$, Putu Aristya Adi Wasita ${ }^{2}$, \\ Luh Diah Citraresmi Cahyadi ${ }^{3}$, Rai Gina Artaninggrum ${ }^{4}$ \\ ${ }^{1234}$ Universitas Dhyana Pura
}

emailsripurnama@undhirabali.ac.id, ariswasita@undhirabali.ac.id, diahcitraresmi@undhirabali.ac.id, raigina86@undhirabali.ac.id

\begin{abstract}
Abstrak
Pemasaran merupakan elemen penting menjalankan sebuah bisnis. Banyak pelaku bisnis yang meluangkan waktunya untuk memikirkan metode pemasaran apa yang tepat agar barang yang dijualnya laku di pasaran. Terlebih saat ini dengan pembatasan gerak dalam masa pandemi Covid-19, mengakibatkan kegiatan lebih dilakukan secara digital. Tujuan pengabdian ini adalah memberikan pelatihan digital marketing bagi peluang bisnis usaha dalam hal ini ibu ibu PWDK GKPB Wilayah Tabanan, diharapkan mereka akan termotivasi untuk menggunakan digital marketing sebagai sarana komunikasi dan peluang bisnis untuk usahanya, serta dapat mempraktikkannya secara langsung dengan memanfaatkan media sosial. Kemudian diperlukan juga pengetahuan terkait dengan pencatatan dalam pelaporan keuangan menggunakan akuntansi sederhana yang dapat mempermudah dalam mengontrol keuangan dan mengetahui peningkatan dari usahanya tersebut.
\end{abstract}

Kata Kunci : digital marketing, kewirausahaan, laporan keuangan

\section{PENDAHULUAN}

Usaha yang didirikan oleh wirausaha adalah salah satu jalan untuk menentukan kemajuan perekonomian. Karena dengan wirausaha maka seseorang akan mampu menciptakan lapangan kerja sendiri dan memberikan kesempatan bekerja untuk orang lain (Andari, 2011). Perilaku kewirausahaan dapat dibina dengan enam ciri utama yaitu percaya diri, berani mengambil resiko, berorientasi tugas hasil, kepimpinan, serta berorientasi ke masa depan untuk tercapainya tujuan (Hakim, 2007). Salah satu cara melakukan wirausaha adalah dengan sosial media. Sosial media merupakan konten yang berisi informasi yang sangat mudah diakses oleh berbagai pihak. Saat ini, praktek pemasaran melalui sosial media mulai berkembang dan digunakan sebagai alat pemasaran produk untuk mempromosikan merek dan brand suatu perusahaan (Harjadi dkk, 2008). Kurangnya pengetahuan masyarakat akan pengetahuan mengenai strategi kewirausahaan dan pemanfaatan aplikasi digital marketing dapat mengubur jiwa wirausaha dan tidak adanya tindak lanjut penjualan produk yang telah dimiliki pelaku usaha.

Perkembangan digital marketing saat ini terlebih dalam masa pandemic Covid-19 kian meningkat dan semua orang bahkan company besar pun beralih menggunakan digital dan meluaskan pemasarannya tanpa menghilangkan teknik lama yang meskipun tidak begitu efektif, namun juga tetap bisa memberikan kontribusi pada income. Dengan beragam hadirnya platform digital yang semakin beragam, tahun 2021 dipastikan trend pemasaran digital semakin naik dan banyak user 
yang akan mengoptimalkan penggunaan digital platform ini untuk berbisnis.

Salah satu media komunikasi yang dapat digunakan pelaku usaha untuk mempromosikan usahanya adalah komunikasi media maya atau media internet. Pelaku usaha dapat memanfaatkan e-commerce dan marketplace yang memberikan peluang yang besar untuk bisa mengekspansi penjualan produk mereka melalui media digital serta penambahan pendapatan keluarga. Wirausaha perlu memanfaatkan bermacam cara untuk melakukan promosi dan meningkatkan penjualan produk mereka, salah satunya dengan memanfaatkan peluang yang ada. Media sosial berpotensi untuk membantu pelaku usaha dalam memasarkan produknya (Stelzner, 2012).

Aplikasi media sosial tersedia mulai dari pesan instan hingga situs jejaring sosial yang menawarkan pengguna untuk berinteraksi, berhubungan, dan berkomunikasi satu sama lain. Aplikasi-aplikasi ini bermaksud untuk menginisiasi dan mengedarkan informasi online tentang pengalaman pengguna dalam mengkonsumsi produk atau merek, dengan tujuan utama meraih (engage) masyarakat. Dalam konteks bisnis, people engagement dapat mengarah kepada penciptaan profit. Selain pemahaman distribusi produk pelaku usaha juga perlu disertai dengan pemahaman faktorfaktor pendukung dalam melakukan kegiatan bisnis seperti pembukuan sederhana sehingga pelaku usaha hanya fokus pada profit semata tanpa memperhatikan faktor-faktor pendukung usaha.

Adapun pelaksanaan pelatihan pemasaran digital online didasarkan pada konsep sebagai berikut. Pentingnya manajemen pemasaran online atau digital bagi wirausaha bertujuan salah satunya adalah untuk melakukan perluasan pangsa pasar, dan efektivitas cara pemasaran. Pendekatan pemasaran 4.0 adalah menggabungkan interaksi online dan offline antara pelaku usaha dan pelanggan, memadukan gaya dengan substansi dalam membangun merek, dan akhirnya melengkapi konektivitas mesin-mesin dengan sentuhan manusia ke manusia untuk memperkuat keterlibatan pelanggan. Marketing 4.0 membantu pemasar beralih ke ekonomi digital, yang mendefinisikan ulang konsep kunci dari pemasaran. Pemasaran tradisional dan pemasaran digital dimaksudkan untuk dipadukan dengan tujuan mendapatkan pembelaan pelanggan (Kotler, 2019). Pada usaha UMKM terdapat beberapa kendala internal untuk terjun pasar global diantaranya masalah sumber daya manusia, produk, teknologi, informasi, networking dan pemasaran. Adapun kendala eksternalnya adalah bahasa, budaya, daya saing, penipuan, perubahan zaman, risiko keuangan, dan kondisi ekonomi (Dhewanto, 2018). Berdasarkan hal yang telah diterangkan tersebut maka pengabdian ini melakukan pelatihan pemasaran online dan offline bagi pelaku usaha agar dapat melakukan pemasaran lebih luas bahkan siap untuk mendunia dengan penggunaan teknologi dan sistem informasi yang telah tersedia.

Selain penggunaan teknologi untuk memasarkan produk, pelaku usaha perlu melakukan pencatatan laporan keuangan yang sistematis. Dengan pencatatan keuangan memberi manfaat, yaitu dapat memberikan informasi kas yang dapat dipercaya mengenai posisi keuangan usaha pada suatu saat tertentu, dapat memberikan informasi keuangan mengenai hasil usaha pada satu periode akuntansi, dan informasi lainnya yang dapat membantu berbagai pihak yang berkepentingan untuk menilai kondisi dan potensi suatu usaha serta dapat memberikan informasi penting lainnya (Maulani, 2016).

Ibu ibu Persekutuan Wanita Dian Kristawati Gereja Kristen Protestan di Bali (PWDK GKPB) wilayah Tabanan merupakan ibu ibu yang sebagian besar memiliki usaha dan baru merintis usaha. Berdasarkan analisis situasi terdapat masalah utama dalam pengembangan usaha yaitu minimnya pengetahuan Ibu PWDK GKPB Wilayah Tabanan mengenai digital marketing dan pencatatan keuangan. Hal tersebut menginspirasi beberapa dosen dari Prodi Akuntansi untuk melakukan pengabdian masyarakat terkait permasalahan yang dihadapi oleh ibu ibu PWDK GKPB Wilayah Tabanan. Kegiatan PKM ini bertujuan memberikan pengetahuan/pelatihan tentang pelatihan pengembangan kewirausahaan dan pemanfaatan aplikasi digital marketing serta pencatatan keuangan agar ibu ibu PWDK GKPB Wilayah Tabanan dapat berwirausaha dan memasarkan produk dan mengetahui keuangan dari usaha yang dikerjakan. Kegiatan ini juga merupakan bentuk keterlibatan 
perguruan tinggi dalam melaksanakan Tridharma perguruan tinggi dan memberikan pemahaman dan sosialisasi kepada pelaku usaha usaha kecil mengenai strategi-strategi pemasaran yang tepat agar dapat mengoptimalkan profit yang diinginkan.

\section{METODE}

Kegiatan PKM dilaksanakan dengan sasarannya meningkatkan kualitas sumber daya manusia melalui pelaksanaan pelatihan penggunaan media digital untuk memasarkan produk dan peserta mampu membuat pembukuan sederhana dan meningkatkan pemasaran produk secara online atau digital. Metode pelaksanaan yang digunakan dari kegiatan pelatihan penggunaan media digital dan pembuatan pembukuan keuangan dan pemasaran online adalah sebagai berikut. Kegiatan diawali melakukan koordinasi dengan Pengurus PWDK GKPB Wilayah Tabanan tentang kebutuhan pendampingan pengajaran penggunaan media digital dalam pemasaran dan pembuatan laporan keuangan yang perlu diberikan dalam pengabdian masyarakat baik secara teori maupun praktikum. Dilanjutkan dengan sesi pelatihan yang menitik beratkan pada kemampuan membuat bahan pemasaran dengan menggunakan media digital dan pembuatan laporan keuangan. Pemberian pelatihan ini dilakukan dengan teknik simulasi agar para pelaku usaha mendapatkan pengalaman langsung sekaligus pengayaan dari tim pelatih. Terakhir tahap Evaluasi dan Penutup, dimana permasalahanpermasalahan yang ditemukan dari peserta pelatihan menjadi bahan diskusi dan kajian bersama, kemudian ditawarkan solusi alternatifnya sebagai solusi akhir. Kemudian diberikan kesimpulan dan penutup dari hasil kegiatan secara jelas dan menyeluruh.

Untuk metode pelaksanaan pengabdian masyarakat menggunakan beberapa metode pelatihan, yaitu: 1) Metode ceramah untuk memberikan penjelasan bagi ibu ibu PWDK GKPB Wilayah Tabanan untuk mengetahui media digital yang dipergunakan untuk memasarkan produk kewirausahaan dan mengaplikasikannya di dunia usaha serta laporan keuangan yang diperlukan dalam menjalankan usaha; 2) Metode tanya jawab sangat penting bagi para peserta pelatihan, baik di saat menerima penjelasan tentang topik yang dibahas serta saat mempraktekkannya; 3) Metode Simulasi diberikan kepada para peserta pelatihan untuk mempraktekkan materi pelatihan yang diperoleh.

\section{HASIL DAN PEMBAHASAN}

Program kegiatan pengabdian kepada masyarakat berupa pelatihan digitalisasi pengembangan kewirausahaan dan pembuatan laporan keuangan sederhana. Setelah selesai melakukan persiapan, selanjutnya dilakukan koordinasi Pelaksanaan yang dilakukan bersama dosen, PWDK Wilayah Tabanan. Persiapan yang dilakukan adalah menyiapkan sarana, prasarana dan alat keperluan pelatihan seperti media sosial untuk digitalisasi pemasaran produk, peralatan tulis, buku kas dan presentasi tentang pembukuan. Kegiatan pengabdian dilaksanakan mulai pada tanggal 5, 20 dan 29 Juni 2021 bertempat di GKPB Jemaat Immanuel, Tabanan, Bali dengan jumlah yang berjumlah 64 orang. Sebagian dari peserta telah memiliki usaha, dan sebagian sedang dipersiapkan untuk membuka usaha baru.

Penyuluhan materi di awal kegiatan adalah mengenai pengenalan aplikasi secara digital dan pengelolaan keuangan untuk mempermudah pencatatan keuangan pada usaha UMKM Ibu Ibu PWDK GKPB Tabanan. Peserta diberikan edukasi terlebih dahulu mengenai pentingnya pencatatan keuangan dalam kegiatan bisnis/usaha yang sedang dilakukan. Masih banyak usaha kecil yang sedang berkembang tanpa adanya pencatatan keuangan yang dilakukan secara khusus serta masih mencampurkan antara pendapatan usaha dengan keluarga (Saptono dkk., 2016) Usaha akan sulit berkembang dengan kondisi seperti ini serta sulit dilaksanakan karena tercampur dengan kegiatan rumah tangga.

Pelatihan digitalisasi kewirausahaan memberikan wawasan tentang perilaku konsumen dalam mencari produk yang diharapkan yaitu memberikan pelatihan tentang bagaimana menulis caption, hashtag, dan peran like maupun comment agar mudah dicari oleh konsumen dan meningkatkan trust building hingga menentukan waktu yang tepat untuk posting di akun medsos agar 
sesuai dengan "jam hidup" segmentasi konsumennya.

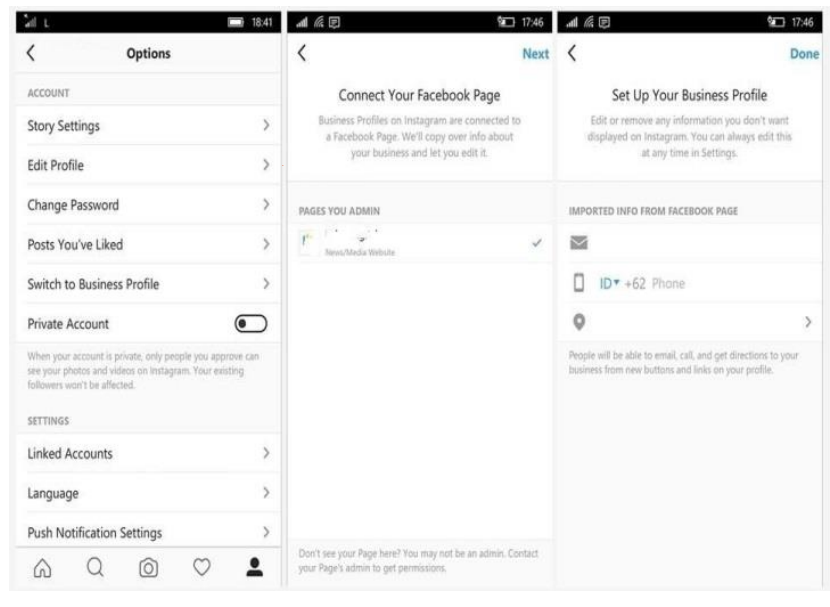

Gambar 1. Pembuatan Akun Istragam

Selain memberikan pelatihan tentang digital marketing, program pengabdian masayarakat juga memberikan pelatihan pembuatan laporan pembukuan. Dalam pelatihan pembuatan laporan keuangan, ibu ibu PWDK diberi pelatihan bagaimana cara membuat laporan keuangan yang baik dan benar baik itu dari pencatatan tranksaksi baik itu trasaksi penerimaan kas maupun pengeluaran kas, pembuatan buku besar sampai membuat laporan keuangan. Banyak dari peserta masih kurang paham dalam melakukan proses pelaporan keuangan sehingga perlu di lakukan latihan secara bertahap. Permasalahan lainnya adalah belum adanya pemisahan keuangan antara bisnis dan rumah tangga, target pendapatan masih berdasarkan pada besarnya modal yang dikeluarkan, pencatatan hanya dilakukan pada pos pengeluaran dengan mengesampingkan pos pemasukan.

Pelaksanaan program pengabdian kepada masyarakat terlaksana sampai dengan tahap kemampuan pemasaran online dan pembuatan laporan keuangan, ada tahap selanjutnya dilakukan pemantauan dan pendampingan, serta implementasi pelatihan pada usaha yang mereka lakukan. Hasil pelaksanaan pengabdian secara keseluruhan sesuai dengan target, yaitu ibu ibu PWDK wilayah Tabanan yang menjadi mitra usaha yang telah mengikuti pelatihan mampu melakukan pemasaran produk secara online dan pembukuan keuangan sederhana.

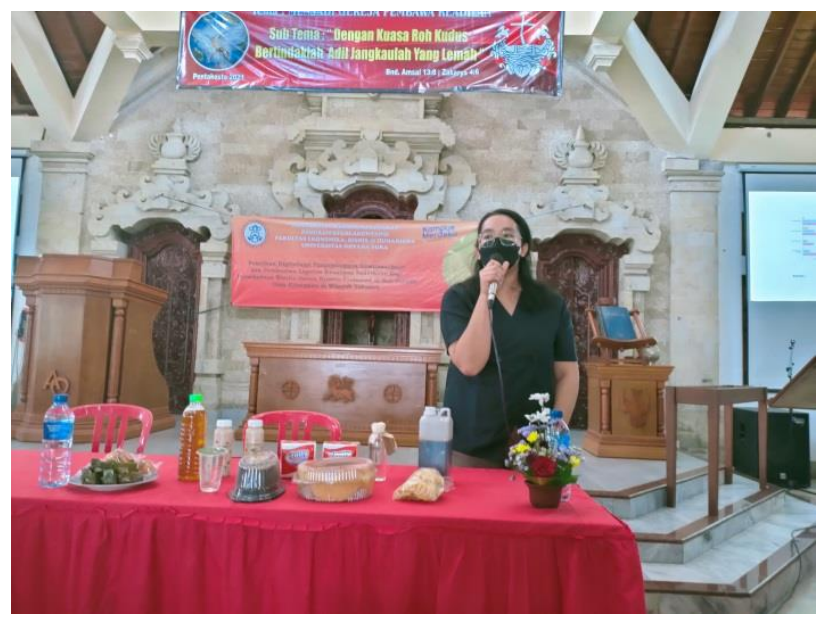

Gambar 2. Penyuluhan Penggunaan Media Sosial Untuk Pelaku Usaha

Pelaksanaan pelatihan digitalisasi pemasaran produk kewirausahaan dan pembuatan pembuatan laporan keuangan sederhana dapat disimpulkan sesuai dengan target dan tujuan. Ibu ibu PDWK mampu mampu menggunakan teknologi informasi dan media sosial untuk mendesain cara promosi, meningkatkan pasar produk, memperluas pangsa pasar. Serta membuat laporan keuangan, sehingga dapat mengetahui seberapa besar keuntungan usaha, mengatur arus kas dan dapat memprediksi bagaimana peningkatan usaha di waktu yang akan datang. Dengan digitalisasi kewirausahaan selain itu ibu ibu PWDK wilayah Tabanan menambah kemampuan membuat produk yang inovatif, mendesain kemasan, promosi produk, cara pemasaran secara online/ digital, selain itu pemasaran sebagian tetap menggunakan cara-cara tradisional atau tatap muka langsung. Jadi pelaku usaha dapat melakukan pemasaran dan penjualan kombinasi antara cara tradisional dan digital/online.

Setelah mengikuti pelatihan mitra mampu memiliki keterampilan dan informasi mengenai pembuatan pembukuan sederhana tentang kredit dan debit. Selain itu mitra dapat mengetahui kegunaan dari ketertiban tentang pembukuan keuangan dalam usaha, mengetahui segmentasi pasar yang tepat akan produk usaha yang dihasilkan selama ini, mengetahui kegunaan teknologi secara maksimal 
terutama handphone dan aplikasi yang ada untuk perluasan pasar usaha. Sesuai dengan tuntutan pada saat ini maka mitra mampu menggunakan secara maksimal internet untuk melakukan promosi dan perluasan produk usaha dengan menggunakan media sosial seperti whatsapp, facebook, dan instagram.

Dengan adanya pelatihan digitalisasi pemasaran produk kewirausahaan dan pembuatan pembuatan laporan keuangan sederhana maka dapat mencapai tujuan dari pelaksanaan pengabdian kepada masyarakat: 1) Ibu ibu PWDK GKPB Wilayah Tabanan mampu melakukan perluasan pasar dengan menggunakan pemasaran dengan sistem online dan digital. 2) Ibu ibu PWDK GKPB Wilayah Tabanan Pelaku usaha untuk meningkatkan kemampuan membuat laporan keuangan usaha.

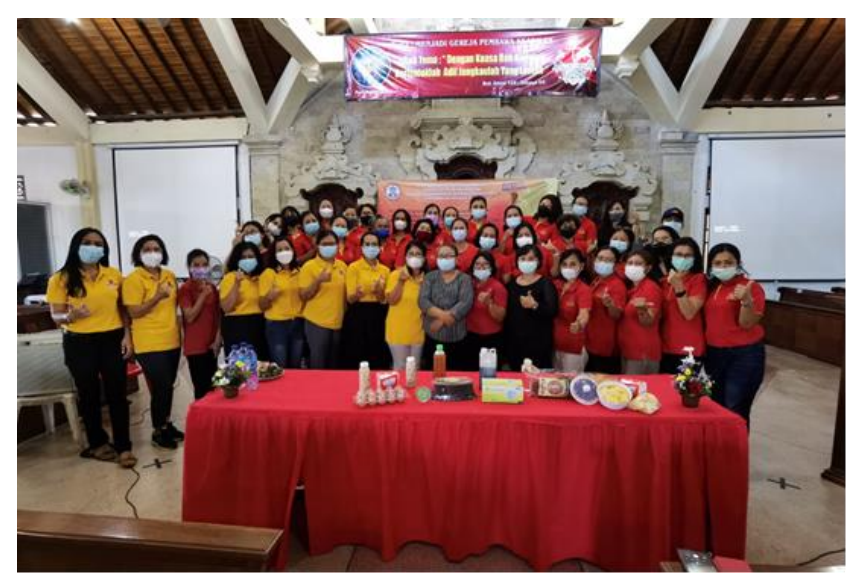

Gambar 3. Peserta Pelatihan Digitalisasi Keuangan dan Pembuatan Laporan keuangan Sederhana

\section{KESIMPULAN}

Pelatihan digitalisasi pemasaran produk kewirausahaan dan pembuatan pembuatan laporan keuangan sederhana dapat disimpulkan yaitu: 1) Ibu ibu Pengurus PWDK Wilayah Tabanan memberikan dukungan dan bersemangat untuk bekerja sama meningkatkan pemasaran produk secara digital; 2) Selain memasarkan produk Ibu ibu PWDK juga mampu membuat pembukuan keuangan sederhana.

\section{UCAPAN TERIMAKASIH}

Tim berterima kasih kepada beberapa pihak yang telah membantu pelaksanaan kegiatan: 1) Lembaga Penelitian dan Pengabdian Masyarakat Universitas Dhyana Pura yang mendukung pelaksanaan kegiatan pengabdian masyarakat ini; 2) Pengurus PWDK GKPB Wilayah Tabanan yang menjadi mitra pelaksanaan pengabdian masyarakat ini serta kepada pihak yang memberikan gagasan, saran, masukan serta pandangan dalam kegiatan pengabdian ini.

\section{REFERENSI}

Dhewanto, W. (2018). Internasionalisasi UMKM Usaha Kecil Mikro Menuju Pasar Global. Yogyakarta: CV Andi Offset.

Hakim, A. (2006) "Analisis pengaruh motivasi, komitmen organisasi, dan iklim organisasi terhadap kinerja pegawai, studi pada dinas perhubungan dan telekomunikasi propinsi Jawa Tengah, JRBI Vol.2, No.2 PP 165180."

Hasan, A. (2013). Marketing dan Kasus-Kasus Pilihan. Yogyakarta: CAPS.

Harjadi, D \& Fatmawati, (2008) "Word Of Marketing (WOM) Communication Sebagai Alternatif Kreatif Dalam Komunikasi Pemasaran". JURNAL EQUILIBRIUM. Vol.4, No.8, Juli-Desember 2008; 72-78.

Kingsnorth, S. (2016). Digital Marketing Strategy: An Integrated Approach to Online Marketing. Philadelphia: Kogan Page.

Kotler, P. (2019). Marketing 4.0 Bergerak dari Tradisional ke Digital. Jakarta: PT Gramedia.

Maulani, Septina Terra. (2016). Pelatihan Pembukuan Keuangan Sederhana dan Motivasi Kewirausahaan pada Kelompok Usaha Makanan RW 02 Kelurahan Neglasari Kecamatan Cibeuying Kaler Bandung. Bandung. Jurnal Dharma Bhakti STIE Ekuitas, Vol.,01, No.1. 32-38.

Ressa, A. (2011). Pengaruh kompetensi pengusaha, skala usaha dan saluran pemasaran terhadap keberhasilan usaha (survey pada industri bawang goreng di kabupaten kuningan). 

Skripsi UPI Bandung.Tersedia di: repository.upi.edu3.
Saptono, A., Dewi, R. P., \& Suparno, S. (2016). Pelatihan Manajemen Usaha Dan Pengelolaan Keuangan Ukm Bagi Tenaga Kerja Indonesia (TKI) Purna Di Sukabumi Jawa Barat. Sarwahita, 13(1), 6-14.
Stelzner, MA (2012). Social Media Marketing Industry Report. How Marketers Are Using Social Media to Grow Their Business. marketing : teknologi berbiaya murah, inovatif, dan berdaya hasil gemilang. Jakarta: Elex Media Komputindo.
Sanjaya, R., \& Tarigan, J. (2009). Creative digital https://doi.org/10.21009/sarwahita.131.0 